\title{
SOIL TRANSMITTED HELMINTH INFECTION AND EOSINOPHIL COUNT IN STUDENTS OF ELEMENTARY SCHOOL
}

\author{
Ririh Jatmi Wikandari ${ }^{\mathrm{a}^{*}} ;$ Nurul Qomariyah $^{\mathrm{b}}$; Sunarto Sunarto ${ }^{\mathrm{c}}$ \\ ${ }^{a, b}$ Department of Health Analyst ; Poltekkes Kemenkes Semarang ; 115 Wolter \\ Monginsidi Street ; Semarang 50192 ; Indonesia \\ c Department of Nutrition ; Poltekkes Kemenkes Semarang ; 115 Wolter Monginsidi \\ Street; Semarang 50192 ; Indonesia
}

\begin{abstract}
Helminth infections are common in children. This infection attacks more children because their activities are more related to the soil, and the child's diet does not recognize hygiene and hygienic food quality. Diagnosis is done by stool examination to find helminth eggs, can also be supported by eosinophil examination. The purpose of this study was to determine the relationship of helminthiasis with the number of peripheral blood eosinophils in student's elementary school Gebangsari 01. This study was an observational study using a cross-sectional approach. The population was 40 students in grades 3 and 4 . The sample is a total population of 40 people. Fourteen students were not infected with soil transmitted helminth and the eosinophil count was normal. Most students have a clean and healthy lifestyle until $100 \%$ negative worm infections. There is no relationship between behavior with the number of eosinophils of student's in elementary school Gebangsari 01.
\end{abstract}

Keywords: helminth infection; eosinophils; elementary school students

\section{Introduction}

Helminth infection prevalence in Indonesia is still high between $40-60 \%$. The highest prevalence occurs in school-age children $21 \%$ of which are found in elementary school-age children (5-14 years) (Kementerian Kesehatan RI, 2012) (World Health Organization, 2012). Based on data from the Semarang City Health Office the percentage of intestinal helminths in school-age children (5-14 years) is $30 \%$. soil transmitted helminth infections rarely cause death, common acute symptoms associated with soil transmitted helminth infections such as abdominal pain, diarrhea, and pruritus, as well as chronic symptoms, such as anemia, malnutrition, and cognitive impairment (Yap et al., 2012) (Hairani, Waris, \& Juhairiyah, 2014) (Salam \& Azam, 2017).

Helminth infection attacks more elementary school children because their activities are more

\footnotetext{
*) Corresponding Author (Ririh Jatmi Wikandari)

E-mail: j.ririh@gmail.com
}

related to soil, besides that elementary school children do not recognize hygiene and hygienic food quality. Based on observations when students take a break, many students still snack outside school, while eating and drinking do not always wash their hands first, even though the school provides clean water faucets for hand washing. During sports and after the midday prayer, many students take off their shoes so that the activity is carried out without using footwear, this behavior is a risk factor that allows students to be exposed to intestinal helminths. Based on information from the school that the Public health center or other related offices have never done helminth examination of student's in elementary school Gebangsari 01.

Enforcement of the diagnosis of infectious diseases caused by helminths carried out laboratory tests to find helminth eggs in feces. The diagnosis can also be helped by blood tests with the discovery of eosinophils (Bestar, Supargiyono, Sumarni, \& Suyoko, 2015). Increased eosinophil levels can be used as a 
marker of soil transmitted helminth infection. Increased eosinophils will cause eosinophilia, which is defined as eosinophil levels of more than $400 \mu \mathrm{L}$ in the blood or more than $4 \%$. In soil transmitted helminth infections, increased levels of eosinophils are related to their function, which is to kill parasites and destroy abnormal cells. (Nathasia, Wahongan, \& Bernadus, 2016) (Darlan, Tala, Amanta, Warli, \& Arrasyid, 2017).

\section{Method}

This study is an observational study with a cross-sectional approach. The population of this study was 40 students in grades 3 and 4 . The sample was taken from the entire population, namely 40 people. Behavioral data collection was obtained through questionnaires and data on worm infections and total eosinophils in stool and capillary blood examination.

Tools and materials used include stool pots, plastic spoons, glass objects, glass decks, drop pipettes, test tubes, test racks, centrifuges, microscopes, feces, peripheral blood, eosin, distilled water, alcohol, lysol. Stool examination to find worm eggs using sedimentation methods and reading of peripheral blood smear to calculate eosinophils.

The examination results were processed and presented in a tabulation and presented descriptively about the relationship between helminthiasis infection with the number of eosinophils in students of elementary school Gebangsari 01, Genuk District, Semarang City.

\section{Result and Discussion}

Feces samples and blood smear preparations collected as many as 40 . Based on the results of the stool examination showed that as many as 40 children were known to not be infected with soil transmitted helminth or found helminth eggs and eosinophil examination results of the 40 children, it was known that the eosinophil value was normal $(0-4 \%)$ (Table 1$)$. This result is different from the research conducted by (Kamila, Margawati, \& Nuryanto, 2018) in elementary school or Madrasah Ibtidaiyah in Bandarharjo Village, Semarang, which received a helminth prevalence of $2.7 \%$. The prevalence of helminthiasis in the Kamila study was caused by helminthiasis who were infected with habit often not washing their hands with soap before eating or after defecation. In addition, the subject had never taken helminth medicine before.
Table 1. Characteristic of Respondents Based on The Result of Feces and Eosinophils Count

\begin{tabular}{ccccc}
\hline \multirow{2}{*}{ Grades } & \multicolumn{2}{c}{ Feces } & \multicolumn{2}{c}{ Result } \\
& Positive & Negative & Increase & Normal \\
\hline 3 & - & 13 & - & 13 \\
4 & - & 27 & - & 27 \\
\hline Count & - & 40 & - & 40 \\
\hline
\end{tabular}

The results of helminthiasis examination on students in grade 3 and 4 elementary school Gebangsari 01 did not find that students were affected by helminthiasis, this is because students have lived a clean and healthy life. This condition is seen in Table 2 give an illustration that students always wash their hands with soap. Hand washing with soap can reduce the risk the entry of the virus into the body (Kementerian Kesehatan RI, 2020). Soap can clean dirt and kill germs because without soap, dirt remains in the hands (Departemen Kesehatan RI, 2015).

Table 2. Clean and Healthy Living Behavior

\begin{tabular}{llcccc}
\hline \multirow{2}{*}{ Behavior } & \multicolumn{2}{c}{ Grade 3 } & \multicolumn{2}{c}{ Grade 4 } \\
& No & Yes & No & Yes \\
\hline - & $\begin{array}{l}\text { Handwashing with } \\
\text { Soap Habits }\end{array}$ & - & 13 & - & 27 \\
$-\begin{array}{l}\text { Playing Habits on } \\
\text { the Play Ground }\end{array}$ & 6 & 7 & 16 & 11 \\
- & & & & \\
- Use of Footwear & - & 13 & 25 & 12 \\
- Nail hygiene & 1 & 12 & 1 & 26 \\
$-\quad \begin{array}{l}\text { Snacking habits } \\
\text { Defecation habits }\end{array}$ & 2 & 11 & 2 & 25 \\
& 1 & 12 & - & 27 \\
\hline
\end{tabular}

Grades III students play on the ground more often than grades IV students. Students always wear footwear when outside the home, at school, when exercising, and playing on the ground. Use of footwear needs to be done so that: The foot was not injured or stabbed by a sharp object. Prevents diseases, such as worms caused by feces (Menteri Kesehatan, 2017) (Kementerian Sosial RI, 2020). The habit of cleaning nails (nail hygiene), grade IV students cut nails more often than grade III students. The behavior of cutting and cleaning nails is done at least once a week with purpose for prevents diseases that can be transmitted through the remnants of embedded dirt nails and fingers (Kementerian Sosial RI, 2020).

Grades IV students prefer snacks compared to grades III students and snacks purchased in packaged conditions. The food eaten is a healthy snack. Unhealthy snacks, can be contaminated with germs that cause disease (Departemen Kesehatan RI, 2015). Grade IV students mostly 
defecate in the toilet (WC). Defecation must use a clean and healthy toilet so that feces do not pollute the environment and cause worms (Departemen Kesehatan RI, 2014).

Table 3. The Eosinophils Count of Student

\begin{tabular}{lcc}
\hline Student grades & $\mathrm{n}$ & Eosinophil count \\
\hline Grades III & 13 & $2.08 \pm 1.32$ \\
Grades IV & 27 & $1.78 \pm 0.97$ \\
\hline
\end{tabular}

Table 3 shows the number of eosinophils of grades 3 students more than grades 4 students. Under normal conditions the amount of eosinophils is $0-4 \%$. The number of eosinophils will increase in conditions of parasitic infections, a soil transmitted helminth, atopic dermatitis, immunodeficiency, etc. (Darlan et al., 2017). An increase in the number of eosinophils is a natural condition in the body's immune response against foreign bodies in the body. Not finding an infection in students indicates that students have a good immune system. Based on the results of the study, the number of eosinophils is normal although there are still students who have a habit of playing on the ground, have poor nail hygiene and have a habit of defecating in rivers and gardens. This is because students have good hygiene habits. The habit of washing hands using soap and water, washing hands every time you eat and after playing on the ground, the habit of wearing footwear, nail hygiene, eating habits, bowel habits are factors associated with efforts to control worm infections. This is consistent with what is stated in Permenkes 2017 (Menteri Kesehatan, 2017).

\section{Conclusion and Suggestion}

Students of elementary school Gebangsari 01 are not infected with worms and the amount of eosinophils is within normal limits. There is no relationship between worm infection and the number of peripheral blood eosinophils in elementary school Gebangsari 01, Genuk Regency, Semarang City. Future studies should be conducted on locations with a high prevalence of worm infections and respondents other than children. The limitation of this study is that the answers to the questionnaires given by the respondents do not indicate the actual situation. There is no conflict of interest in this article.

\section{Acknowledgments}

Thank you to the Poltekkes Kemenkes Semarang for funding this research activity and all those who have helped with this activity.

\section{References}

Bestar, R. S., Supargiyono, Sumarni, \& Suyoko. (2015). Derajad Eosinofilia Pada Penderita Infeksi Soil-Transmitted Helminth (soil transmitted helminth). Biomedika, 7(2), 27$34 . \quad$ Retrieved from http://journals.ums.ac.id/index.php/biom edika/article/view/1897

Darlan, D. M., Tala, Z. Z., Amanta, C., Warli, S. M., \& Arrasyid, N. K. (2017). Correlation between Intestinal Parasite Infection and Eosinophil Levels among Elementary School Children in Medan. Journal of Medical Sciences, 5(2), 117 - 120. https://doi.org/10.3889/oamjms.2017.014

Departemen Kesehatan RI. (2014). Booklet Perilaku Hidup Bersih dan Sehat di Rumah Tangga. In Departemen Kesehatan RI (pp. 1-48). Jakarta.

Departemen Kesehatan RI. (2015). Aku Sehat Sekolahku Sehat Prestasiku Meningkat. In Departemen Kesehatan RI (pp. 1 - 42). Jakarta.

Hairani, B., Waris, L., \& Juhairiyah. (2014). Prevalensi Soil Transmitted Helminth ( soil transmitted helminth ) pada Anak Sekolah Dasar di Kecamatan Malinau Kota Kabu. Jurnal Buski, 5(1), 43-48.

Kamila, A. D., Margawati, A., \& Nuryanto. (2018). Hubungan Kecacingan Dengan Status Gizi Dan Prestasi Belajar Pada Anak Sekolah Dasar Kelas Iv Dan V Di Kelurahan Bandarharjo Semarang. Journal of Nutrition College, 7(2), 77. https://doi.org/10.14710/jnc.v7i2.20826

Kementerian Kesehatan RI. (2012). Pedoman Pengendalian Kecacingan. Jakarta: Kementerian Keseatan RI.

Kementerian Kesehatan RI. (2020). Panduan Cuci Tangan Pakai Sabun (CTPS) (pp. 1-34). pp. $1-34$.

Kementerian Sosial RI. (2020). Perilaku Hidup Bersih dan Sehat (PHBS) Penguatan Kapabilitas Anak dan Keluarga. Jakarta.

Menteri Kesehatan. (2017). Permenkes RI Penanggulangan Cacingan (pp. 1-37). pp. 1-37. Jakarta. 
Nathasia, T., Wahongan, G., \& Bernadus, J. (2016). Survei Kecacingan Pada Anak Dengan Riwayat. Jurnal Kedokteran Klinik, 1(1), 92-97.

Salam, N., \& Azam, S. (2017). Prevalence and Distribution of Soil-Transmitted Helminth Infections in India. BMC Public Health, 17(1), https:// doi.org/10.1186/s12889-017-4113-2 World Health Organization.

(2012).

Soil-Transmitted Helminthiases:

Eliminating Soil-Transmitted Helmnthiases as a Public Health Problem in Children. In World Health Organization. France.

Yap, P., Fürst, T., Müller, I., Kriemler, S., Utzinger, J., \& Steinmann, P. (2012). Determining Soil-transmitted Helminth Infection Status and Physical Fitness of School-aged Children. Journal of Visualized Experiments,

(66). 